\title{
The Relationship between Corporate Governance and Firm Performance: The Effect of Internal Audit and Enterprise Resource Planning (ERP)
}

\author{
Amjaad I. Alsurayyi, Sulaiman A. Alsughayer \\ College of Economics and Administrative Sciences, Imam Mohammad Ibn Saud Islamic University, Riyadh, Saudi Arabia \\ Email: sasojur@imamu.com.sa
}

How to cite this paper: Alsurayyi, A. I., \& Alsughayer, S. A. (2021). The Relationship between Corporate Governance and Firm Performance: The Effect of Internal Audit and Enterprise Resource Planning (ERP). Open Journal of Accounting, 10, 56-76. https://doi.org/10.4236/ojacct.2021.102006

Received: March 6, 2021

Accepted: April 26, 2021

Published: April 29, 2021

Copyright $\odot 2021$ by author(s) and Scientific Research Publishing Inc. This work is licensed under the Creative Commons Attribution International License (CC BY 4.0).

http://creativecommons.org/licenses/by/4.0/

(c) (i) Open Access

\begin{abstract}
This research aims to explore the effect of good corporate governance on the performance of listed companies in Saudi Arabia. In particular, the research focuses on the effect of effective internal audit and ERP on corporate governance and, subsequently, firm performance. A questionnaire was used to collect the data. The results indicated that effective corporate governance could be attained by having a good internal audit and ERP system. The results conclude that proper corporate governance positively affects firm performance, and effective internal audit activities and successful ERP implementation enhance corporate governance, eventually leading to better performance. The findings of this study are beneficial to Saudi listed companies and other GCC and their policymakers since social, political, and economic contexts are similar. Even though the study's findings provide extensive evidence regarding corporate governance and firm performance, this study has its limitation as respondents represented a small sample of listed companies and cannot be generalized to all listed companies.
\end{abstract}

\section{Keywords}

Firm Performance (FP), Corporate Governance (CG), Internal Audit (IA), Enterprise Resource Planning (ERP), Saudi Arabia (SA)

\section{Introduction}

In recent years, corporate governance (CG) has received considerable attention in the business environment after multiple global crises. CG is seen as a critical tool in building marketplace confidence and attracting investors in all compa- 
nies globally. Setting standards and procedures of good CG is essential for ensuring investor rights, reducing risks, and improving firm performance (Ahmed \& Hamdan, 2015). Researchers are motivated by an expectation that CG regulations might help address issues of corporate accountability, responsibility, corruption, and transparency and thereby improve corporate performance by reducing corporate financial risk (Al-Bassam et al., 2018).

Gillan and Starks (1998) define CG in a broad perspective as "the system of laws, rules, and factors that control operations at a company" (p.4). Hence, CG is a combination of rules and actions designed to increase transparency and fairness in the relationship between the firms and its shareholders that facilitate the shareholders' decision-making process and avoid conflicting interests. This research explores the relationships between CG and firms' performance in Saudi listed companies focusing on specific factors, i.e., internal audit and Enterprise Resource Planning (ERP). Several factors could affect CG practices and performance, and it is beyond the scope and objective of this study to explore them all. Only a modest body of literature in Saudi Arabia explores these two factors' effect on CG practices and, subsequently, firm performance. Effective internal audits and advanced information systems, such as an ERP system, can support proper CG practices. This research explores how effective internal audit and successfully implemented ERP affect and enhance CG leading to better firm performance.

The lack of research about the role of effective internal control and successful ERP on CG practice, especially in Saudi Arabia has given this study great importance. This study makes several contributions to the CG literature in general, and Saudi Arabia in particular. The findings provide contributions to many stakeholders, including policymakers, regulators, academics, and the wider community in understanding the issues and current state of CG practices in Saudi Arabia. Further, this study can be generally helpful for researchers investigating the implications of CG principles and CG practices in improving firm performance, as this study is one of the few studies covering this subject.

The remaining of the research is organized in four sections. The first section presents the literature review related to the topic of this study and develops the research hypothesizes. Section two presents the research methodology: the data collection and selected sample. Section three discusses the results, followed by the last section outlining the conclusion and recommendations.

\section{Literature Review and Hypothesis Development}

\subsection{Corporate Governance}

Interests in CG have increased recently, especially with the announcement of financial scandals around the world. Nowadays, CG plays a vital role in any business environment. The term CG has no generally accepted definition. Nevertheless, it can be perceived from a narrow or broad perspective, depending on the viewpoint of the policymaker, professional, researcher, or theorist (Solomon, 
2007). The broad perspective takes into account all stakeholders, such as shareholders, customers, and suppliers. Using the broad perspective, Gillan and Starks (1998) define CG as "the system of laws, rules, and factors that control operations at a company" (p.4). Similarly, the ASX Corporate Governance Council (2006) defines CG as: "the framework of rules, relationships, systems and processes within and by which authority is exercised and controlled in corporations. It encompasses the mechanisms by which companies, and those in control, are held to account" (p.4). In this sense, CG influences the way a company set objectives and achieve them, monitor risk and assess it, and control performance and optimize it.

The narrow perspective focuses on the interests of shareholders, which is asserted in agency theory. It simply views that the demand for CG mechanisms comes from the segregation between managers and shareholders (Gillan, 2006). Parkinson (1994) states that the role of CG is to ensure that managers behave in favor of the interests of shareholders. The need for CG arises because of the separation of corporate ownership and its control. From the review of previous studies, CG should be understood through agency theory. Agency theory explains the emergence of CG in a way that a separation between ownership and control gives rise to agency problems but a good governance process reduces the agency risks.

CG is concerned with agency problems, in particular the problem of information asymmetry. It addresses issues regarding the separation of corporate ownership and corporate management. Managers of a company acting as agents for shareholders. Where principals (shareholders) delegate decision-making authority to agents expecting to represent the best interests of the principals but frequently, this can be contrary with the agent interests causing principal agency problems (Jensen \& Meckling, 1976). Thus, there is a demand for good CG that ensures the alignment of the goal between agents and principals.

Agency theory is significant in the current study because it expresses the idea that proper CG is one that clearly states that there is a separation between ownership and control. Agency theory is used in the study to explain the need for the internal audit unit and advanced information systems such as ERP system to ensure that stakeholders are treated fairly and receive the information they need in the proper time and manner.

\subsection{CG in Saudi Arabia}

Many capital market regulators around the world have designed CG guidelines, and Saudi Arabia is no exception. In fact, Saudi Arabia was the second country to adopt CG in the GCC after Oman (Buallay et al., 2017). The legislation regulating the behavior of corporations in Saudi Arabia can be traced to 1965 with the initiation of “The Companies Law", which governs businesses' practice. Since then, Saudi Arabia has witnessed several reforms in relation to CG starting with the special attention given to internal control systems by the Saudi Arabian 
Monetary Agency (SAMA), responsible for developing, operating, regulating, and monitoring the financial and capital markets. In 2000, SAMA issued internal control standards where all Saudi listed companies were called and encouraged to design their internal control systems based on these standards.

Another interesting development in relation to CG took place in 2003 when the Capital Market Authority (CMA) in Saudi, took over the full responsibility of the stock exchange control from SAMA. This remarkable change was followed by the introduction of an online stock exchange known now as Tadawul (Al-Bassam et al., 2018). But the most substantial reform in Saudi occurred in 2006 after the crash of stock market by about $25 \%$. During this time, CMA issued voluntary CG regulations that became compulsory for all Saudi listed companies in 2010 to provide fairness and transparency in Saudi stocks (Buallay et al., 2017). CMA still supervises and controls the adoption of CG Regulations and monitors adherence. Buallay et al. (2017) argue that this regulation was prepared to harmonize with international standards of CG, such as the Organization for Economic Co-operation and Development (OECD).

Saudi's CG Regulations main objective was to provide a universal guideline of rules, regulations, and practice for those companies listed in Tadawul and investors. The regulation contains the rules and standards that regulate the management of listed companies to ensure its compliance with the best governance practices, hence; providing the protection of shareholder's rights and the rights of Stakeholders. CG Regulation includes twelve parts addressing shareholders' rights, boards of directors and interest conflicts, audit committees, internal control, and disclosure procedures (CMA, 2006). Such regulation is still in practice until today and one can assume that the introduction of the regulation has improved the level of governance in most Saudi listed companies.

\subsection{Firm Performance}

The term firm performance is complex and measuring business performance in today's economic environment is a critical issue for academic scholars and practicing managers. Although the term is a prevalent notion in academic literature, there is hardly a consensus about its definition and measurement. Verboncu and Zalman (2005) defined performance as a particular result obtained in management, economics, and marketing that gives characteristics of competitiveness, efficiency, and effectiveness to the firm and its structure.

A firm's performance is basically measured in terms of the efficiency of the firm's functions and operations. The more effective the firm's functions and operations are completed, the more favorable the organizational performance is. Many organizations have attempted to manage firm performance using CG. Effective CG enhances firm performance and maximizes investors' returns, while weak CG may let managers misuse firms' assets (Ahmed \& Duellman, 2007). In this study, firm performance is measured as per the respondent feedback about their overall organizational outcomes and achievements. 


\subsection{CG and Firm Performance}

Numerous researchers have studied the relationship of CG and firm performance. Ahmad and Yameen (2015) explored the impact of CG practices on the shareholders' wealth and financial performance of the organizations and found a positive impact between them. Škare and Hasić (2016) found that good CG helps to achieve higher income growth rates. Ahmed and Hamdan (2015) studied the impact of CG on firm performance in Bahrain listed companies from 2007 to 2011 on a sample of 42 observations using the ROE measure. The results indicated CG is significantly correlated with firm performance. Anwar \& Aziz (2019) explored the relationship between CG practices and firm performance for 762 multinational companies in Asia from 2008 to 2017 based on Agency Theory. The study concluded that good CG practices raise firm performance.

Other studies, however, have reported that CG and firm performance are unrelated (Ebelechukwu et al., 2015; Fallatah \& Dickins, 2012). For example, Ebelechukwu et al. (2015) presented evidence that there is no significant relationship between CG and banks' financial performance. Fallatah and Dickins (2012) explored the relationship between CG characteristics and firm performance in Saudi-listed companies. The results indicated that corporate governance and firm performance are unrelated.

The findings of relevant studies on the impact of CG on firm performance are inconsistent. Further, a review of the literature shows that most studies were carried in developed countries; hence, more studies are needed in developing countries such as Saudi Arabia. This study contributes to the literature by exploring the relationship between CG and firm performance in Saudi listed companies; this leads to the first hypothesis of this study:

H1: There is a positive relationship between corporate governance and firm performance.

\subsection{CG and Internal Audit}

As a result of corporate scandals and the global financial crisis, internal assurance on CG has received significant attention. Nowadays, most companies have an internal audit unit to provide this assurance. Internal audit is defined by the Institute of Internal Auditors as an objective assurance to evaluate and improve the effectiveness of an organization's risk management, control and CG processes (Abdullah et al., 2018). The remarkable development in the internal audit community is made in 1992 by the establishment of the Committee of Sponsoring Organization of the Treadway Commission (COSO) internal control framework. For the first time, management was provided with a unified approach for the evaluation of internal control systems (Giroux \& Cassell, 2011; Martin et al., 2014). COSO's framework for internal control consists of five major control elements: environment, risk assessment, activities, information and communication, and monitoring. Internal audit is linked to these internal control elements, which, if adopted and implemented by businesses, will, as antic- 
ipated by $\mathrm{COSO}$, improve efficiency and effectiveness of operations and compliance with laws and reliability of management and financial reports (COSO, 1992, 2013).

In Saudi Arabia, special attention is given to internal control systems for two decades. As per CG regulations Article 73, the board of a listed company has to approve an internal control system in order "to assess the policies and procedures relating to risk management, implementation of the provisions of the company's governance rules approved by the company and compliance with the relevant laws and regulations" (CMA, 2006: p. 40). Therefore, internal control is important in the organization structure that used to monitor the entity's activities by the management to ensure good governance (Vijayakumar \& Nagaraja, 2012).

The duties of the internal audit unit or department are to assess and monitor the implementation of the internal control system and verify that the company and its employees comply with laws, regulations and instructions, and the company's rules, policies, and procedures. Article 77 of CG regulations states that "the internal audit unit or department shall operate pursuant to a comprehensive audit plan approved by the audit committee. Such a plan shall be updated annually. Key activities and operations, including the activities of risk management and compliance departments, shall be reviewed at least annually" (CMA, 2006: p. 41). As per Article 78, the internal audit unit or department shall prepare and submit a written report on its activities at least quarterly to the board and the audit committee. Such a report shall include an assessment of the internal control system and an opinion with recommendations (CMA, 2006).

Clearly, the role of internal audit in CG comes from the fact that the internal audit determines the reality, integrity, and reliability of operational and financial information to make decisions at all levels of governance (Joksimović \& Alseddig, 2017). Sarens (2009) states that the quality of internal audit has a positive impact on CG quality. An audit committee assures more governance as it reviews the adequacy of the competency of the internal audit function, reduces information asymmetry between stakeholders and managers, and therefore reduces agency problems. Some researchers found that firms are less likely to report financial fraud with audit committees (Al-Matari et al., 2012).

Obviously, internal auditors are expected to provide considerable feedback about their companies' CG to the audit committee and board of director, and the companies, in return, must keep records of the audit reports and business documents, which shall clarify accomplishments, findings, recommendations, and all actions taken in this regard.

Several studies stated that an effective internal audit and internal control system is essential to achieve proper CG practices. Fadilah (2013) pointed that the implementation of internal control contributes to the implementation of good governance. Vlad (2012) suggested that the key elements of good CG include adequate internal control systems and transparency. Dănescu et al. (2011) emphasized that the implementation of adequate internal control activities will lead 
to good CG. Olumbe (2012) explored the relationship between internal control and CG in Kenyan banks and concluded that there is a positive relationship between internal control and CG, leading to improving firm performance and maximizing shareholder value.

Other studies investigated the audit committee's involvement and its effect on internal audit performance quality. Abdullah et al. (2018) concluded that there is an association between the audit committee and high internal audit performance. They recommended the audit committee constantly review internal audit processes to improve audit quality and audit performance. Al-Matari et al. (2012) argue that the audit committee as a governance mechanism reduces information asymmetry between shareholders and managers and prevents agency conflicts.

In contrast, Al-Shetwi et al. (2011) examined the impact of the quality of the internal audit function, as a critical factor of CG structure, on the financial reporting quality of all Saudi listed companies in 2009. The study showed no significant contribution of internal audit quality on financial reporting and a weak association between them due to an inappropriate legal system and poor CG practices. Therefore, the study recommended CMA consider more effective procedures to improve the internal audit.

Another line of studies investigated the relationship between internal audit and audit committee and how this affects performance. Bananuka et al. (2018) conducted a study to examine the role of internal audit functions and audit committee's effectiveness on accountability and performance. They found that internal audit functions and audit committees have a significant positive effect on both. Other studies advocated that the effectiveness of internal audits depends on the availability of adequate, educated, and professionally qualified staff and a continuous professional training program. Ali et al. (2009) studied the effect of lack of qualified staff on internal audit and concluded most of the notable shortcomings related to poor internal audit functions in the selected sample were due to shortage of staff and lack internal audit skills.

Clearly, few existing studies have dealt with the effectiveness of internal audit as a factor leading to good CG. Current researches in Saudi Arabia have rarely focused on studying the relationship of CG and firm performance through the effectiveness of this factor. The second hypothesis of this study fills this gap as follows:

H2: Effective internal audit enhances corporate governance leading to positive firm performance.

\subsection{CG and ERP Implementation}

Information systems are important as governance monitoring mechanisms. One of the most innovative information technology systems is Enterprise resource planning (ERP) systems (Al-Mashari, 2003). It is becoming more recognized that ERP system has a positive consequence on the performance of the whole organization as it is "better, faster, and more economical business solutions" 
(Lopes, 1992: p. 45). Successful ERP systems integrate all functional areas of an organization into a single information system. ERP benefits businesses by streamlining business processes through integration, providing real-time information processing, reducing redundancies, and providing reliable information access. It essentially integrates various business processes, bringing in inherent efficiencies as a result into the enterprise. Because of the benefits of ERP systems, many companies worldwide have implemented these systems (Al-Turki, 2011). ERP helps establish a complete, accurate, timely information flow system and produces standard information for inside and outside stakeholders, making the management and stakeholder levels more transparent (Jidong \& Liyan, 2010).

Information asymmetry exists between shareholders and management in a corporation which leads to serious principal agency problems. Previous studies suggested using information systems such as ERP system helps bridge the information asymmetry gaps between owners and managers, which could reduce the agency problem. Jidong and Liyan (2010) investigated the CG characteristics of companies that implement ERP through all the Chinese listed companies from 1994 to 2006. The study found that information asymmetry is often held to be the cause of many agency problems. Subsequently, an ERP system enhances information flow for internal managers and outside stakeholders, helps resolve principal-agency problems and improves CG. The two researchers concluded that companies with poor CG are more inclined to implement an ERP system. Chen et al. (2019) argued that ERP systems facilitate information availability and integration that influence agency costs, decision information costs, and principal conflicts in corporate governance management. They provided an empirical study by examining CG and ERP's interaction effects on firm performance through Chinese listed companies during 2008 and 2013. They found that ERP implementation is associated with better firm performance under some CG aspects. Few studies have focused on the moderating effect of ERP investments on firm performance. Zhang and Huang (2012) studied the moderating effects of CG, ERP, and industry growth on firm performance through the samples of 137 US listed companies from 1998 to 2007. The results revealed that CG positively moderates the relationship between ERP investments and firm performance.

In the context of Saudi Arabia, Abu-Musa (2007) conducted an empirical study to investigate the performance of information technology governance in Saudi organizations. The result of this study suggests that Saudi organizations should attain better governance of their IT and use their IT resources more responsibly in order to ensure that an organization's IT strategy is aligned with the organization's strategy, further exploiting opportunities and maximize benefits. Consistent with the above arguments, Shaiti (2014) examined the relationship between ERP systems success and internal control procedures conducted in Saudi Arabia. The study's results revealed a significant positive relationship between the success of ERP systems and the effectiveness of internal control procedures. The study found that corporate culture and management support are positively relevant to the effectiveness of internal control procedures. 
Clearly, literature examining the effectiveness of ERP systems on corporate governance is limited in Saudi Arabia. Only a small number of studies have investigated the relationship between ERP systems and CG. This study contributes to this end by testing such relationship which is presented in the third hypothesis:

H3: Successful ERP system improves corporate governance practices leading to better firm performance.

\section{Research Methodology}

To effectively achieve research objectives, researchers should use a methodology that is suitable for the research. For this study, both secondary and primary data collection techniques were employed. The secondary data obtained from reports on CG and internal audit, academics articles, and internet and library sources. With regards to primary data collection, a questionnaire was used to collect data from Saudi listed companies. The questionnaire was developed for this study to explore the effect of effective internal audit and successful ERP systems (as independent variables) on firstly CG (as an intermediate variable) and subsequently firm performance (as dependent variable). Figure 1 summarizes the conceptual model to test the three hypotheses developed in the previous section.

\subsection{Data Collection}

Data were collected through a survey instrument using Google's online form. A self-designed questionnaire was prepared both in English and Arabic based on a comprehensive review of previous literature. The researcher used in both copies a clear, simple, and easy to understand language. A draft of the questionnaire is then sent to experts for review and recommendation. The questionnaires were distributed with a covering introduction to clarify the research objectives and the researcher's guarantee of information security to encourage respondents to answer the listed questions and increase the response rate effectively. The questionnaire was structured in three concise sections to collect information from Saudi listed companies' financial and accounting staff. The three sections addressed the research issues and hypotheses on which data are to be collected. Section one gathers general information regarding the respondent (gender and age), the position of the respondent (CEO, CFO, or audit committee member), and years of experience. Section two and three cover the relationship of effective internal audit and successful ERP on CG and firm performance. All the questions are closed-ended questions except some questions in the general information

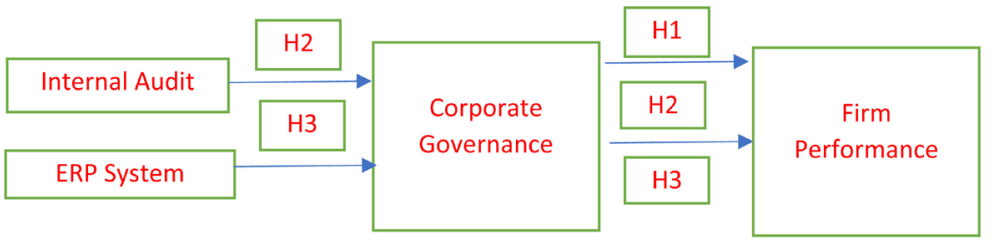

Figure 1. The conceptual model. 
in section one, the firm's name of the participant, and the choice "other (please specify)" in the job title. The respondents were requested to indicate their opinions on a Five-Likert scale point ( $5=$ strongly agree, $4=$ agree, $3=$ neutral, $2=$ disagree, $1=$ strongly disagree). The analysis of mean score is set as follows: less than $1.5=$ very low, $1.5-2.5=$ low, $2.5-3.5=$ moderate, $3.5-4.5=$ high, above 4.5 = very high).

\subsection{Sample}

The sample consists of Saudi listed companies having internal audit units and implementing ERP systems. Financial managers, senior accountants, audit committee members, and internal auditors were selected as key respondents. Also, external auditors auditing listed companies and legal officers at CMA were covered. Out of (120) surveys sent online to respondents, a total of (47) were returned. The actual responses received were a suitable number to carry out this study and to achieve its objectives. Since the question about the firm's name is optional, the exact number of companies that responded to the survey is unknown. The response rate was $39 \%$ which is consistent with the response rate of previous studies. Survey response rates in the $30 \%$ range are far more typical. Holbrook et al. (2007) noted that studies with lower response rates are often only marginally less accurate than those with much higher described response rates. In the study sampling, care has been taken to ensure that the sample selected represents the total targeted population accurately and the questionnaires were sent to respondents versed knowledge in the subject area within the targeted population.

\section{Results and Discussion}

\subsection{General Information of Participants}

The distribution of responses to the questionnaire is presented according to gender, age, education, job position, and work experience. Table 1 presents the distribution of respondents based on gender. The results show that the majority (89.4\%) of respondents were males while only (10.6\%) were females. This result indicates that the majority of employees in Saudi listed companies are males.

Table 2 shows the distribution of respondents based on age. The results show that $17 \%$ of surveyed samples were 20 - 29 years old, whereas $31.9 \%$ and $48.9 \%$ of sample were aged 30 - 39 and 40 - 49 years old.

Overall, $80.85 \%$ of respondents were between the age of $30-49$ years. These results are consistent with expectations because employees who work at top management usually obtain their jobs after having many years of experience.

Table 3 presents the qualification of the respondents. $63.8 \%$ of participants had a bachelor's degree, $31.9 \%$ had a master's degree, and $4.3 \%$ had a PhD. All the participants had completed their bachelor's degrees. None of the participants had a diploma, and this result reflects the high qualification needed for an entry requirement for hiring in listed Saudi Companies. 
Table 1. Frequency distribution of gender.

\begin{tabular}{ccc}
\hline Gender & Frequency & Percentage \\
\hline Male & 42 & $89.4 \%$ \\
Female & 5 & $10.6 \%$ \\
Total & 47 & $100.00 \%$ \\
\hline
\end{tabular}

Table 2. Frequency distribution of age group.

\begin{tabular}{ccc}
\hline Age & Frequency & Parentage \\
\hline $20-29$ & 8 & $17.02 \%$ \\
$30-39$ & 15 & $31.91 \%$ \\
$40-49$ & 23 & $48.94 \%$ \\
$50-59$ & 1 & $2.13 \%$ \\
Total & 47 & $100.00 \%$ \\
\hline
\end{tabular}

Table 3. Frequency distribution of education.

\begin{tabular}{ccc}
\hline Education & Frequency & Percentage \\
\hline Diploma & 0 & $0.00 \%$ \\
Bachelor & 30 & $63.83 \%$ \\
Master & 15 & $31.91 \%$ \\
PHD & 2 & $4.26 \%$ \\
Total & 47 & $100.00 \%$
\end{tabular}

Table 4 illustrates the distribution of the respondents by job position. The highest percentage goes to internal auditors (36.2\%). The percentages for other jobs were $46.8 \%$, including a mixture of fund managers, senior accountants, budget manager public managers, division managers, legal officers, software engineers, and some others.

Table 5 shows that $23.4 \%$ of the respondents had $1-5$ years of work experience. (19.1\%) had 5 - 10 years of work experience. Also, (19.1\%) of respondents had $11-15$ years. Those with work experience of more than 15 years comprised $38.3 \%$ of the sample. (76.5\%) had at least five years of work experience.

\subsection{The Relationship between CG and Firm Performance}

This section presents the results of testing the first hypothesis exploring respondents' perceptions in relation to the positive relation between CG and firm performance in Saudi listed companies. The results in Table 6 show that CG leads to integrity, disclosure, transparency, responsibility, and equality, as this is ranked in the first place by respondents (statement $\# 1$, mean $=4.51, \mathrm{SD}=0.547$ ), which supports previous literature. Also, the vast majority of the respondents agreed that CG leads to respecting the rights of stakeholders (statement \#2, mean $=4.47, \mathrm{SD}=0.620$ ). This result conforms with the literature relating to agency theory. 
Table 4. Frequency distribution of job position.

\begin{tabular}{ccc}
\hline Education & Frequency & Percentage \\
\hline CFO & 4 & $8.5 \%$ \\
Audit Committee & 1 & $2.1 \%$ \\
Internal Auditor & 17 & $36.2 \%$ \\
External Auditor & 3 & $6.4 \%$ \\
Other & 22 & $46.8 \%$ \\
Total & 47 & $100.00 \%$ \\
\hline
\end{tabular}

Table 5. Frequency distribution of experience.

\begin{tabular}{ccc}
\hline Experience & Frequency & Percentage \\
\hline $1-5$ years & 11 & $23.40 \%$ \\
$5-10$ years & 9 & $19.15 \%$ \\
$11-15$ years & 9 & $19.15 \%$ \\
more than 15 years & 18 & $38.30 \%$ \\
Total & 47 & $100.00 \%$ \\
\hline
\end{tabular}

Table 6. Respondents' perceptions towards cg and firm performance.

\begin{tabular}{llrrr}
\hline \multicolumn{1}{c}{ Statements } & Mean & SD & Rank \\
\hline $1 \quad \begin{array}{l}\text { Corporate governance leads to integrity, disclosure, } \\
\text { transparency, responsibility, and equality. }\end{array}$ & 4.51 & 0.547 & 1 \\
$\begin{array}{l}\text { Corporate governance leads to respecting the rights of } \\
\text { stakeholders as prescribed by law and ensure compensation in case } \\
\text { of violation of their rights. }\end{array}$ & 4.47 & 0.620 & 2 \\
$\mathbf{3} \begin{array}{l}\text { Corporate governance encourages the firm's growth and } \\
\text { competitiveness. }\end{array}$ & 4.34 & 0.700 & 3 \\
$\quad$ Average & 4.44 & $\mathbf{0 . 6 2 2}$ & \\
\hline
\end{tabular}

Also, the survey results reveal that participants positively agree on the positive effect of corporate governance on a firm's growth and competitiveness (statement $\# 3$, mean $=4.34, \mathrm{SD}=0.700$ ). This result is in line with previous studies and the OECD that stated the presence of an effective CG encourages firms to use resources more efficiently, thereby underpinning economic growth.

Table 6 illustrates that the means of the three statements are above 4.00 , which indicates that most participants recognized the importance and positive relation of CG to firm performance. Therefore, this confirms the first hypothesis:

H1: There is a positive relationship between corporate governance and firm performance.

\subsection{The Impact of Effective Internal Audit on CG}

This section presents the results of testing the second hypothesis exploring res- 
pondents' perceptions concerning the positive effect of effective internal audit on CG and subsequently firm performance in Saudi listed companied. Table 7 reveals that the most significant statement of this part that says compliance with

Table 7. Respondents' perceptions towards internal audit.

\begin{tabular}{|c|c|c|c|c|}
\hline & Statements & Mean & $\mathrm{SD}$ & Rank \\
\hline 1 & Internal auditor of my firm/audited firms is independent. & 4.02 & 1.073 & 4 \\
\hline 2 & $\begin{array}{l}\text { Internal auditor contributes to the activation of corporate } \\
\text { governance. }\end{array}$ & 3.94 & 1.092 & 5 \\
\hline 3 & $\begin{array}{l}\text { Internal auditors have sufficient knowledge of the standards } \\
\text { that are necessary to activate the principles of governance. }\end{array}$ & 3.66 & 1.027 & 14 \\
\hline 4 & $\begin{array}{l}\text { Internal audit process contains procedures to ensure that } \\
\text { the principles of corporate governance are applied. }\end{array}$ & 3.79 & 0.999 & 11 \\
\hline 5 & $\begin{array}{l}\text { Internal auditor examines the firm's procedures to ensure } \\
\text { compliance with policies, plans, systems, laws and } \\
\text { regulations and the extent of contribution to activating } \\
\text { the principles of corporate governance. }\end{array}$ & 3.94 & 1.009 & 5 \\
\hline 6 & $\begin{array}{l}\text { Internal audit unit provides mechanisms for improving } \\
\text { the performance levels of the company through corporate } \\
\text { governance. }\end{array}$ & 3.62 & 0.945 & 15 \\
\hline 7 & $\begin{array}{l}\text { Internal audit unit ensures that shareholders have the right } \\
\text { to participate and obtain information about the } \\
\text { fundamental changes in the company. }\end{array}$ & 3.55 & 0.951 & 16 \\
\hline 8 & $\begin{array}{l}\text { Internal auditor reports specify clearly } \\
\text { recommendations/potential of problems arising from } \\
\text { audit findings. }\end{array}$ & 3.89 & 0.866 & 7 \\
\hline 9 & $\begin{array}{l}\text { Management seriously views recommendations and } \\
\text { corrective actions from audit report as an avenue for } \\
\text { improvements. }\end{array}$ & 4.06 & 0.845 & 3 \\
\hline 10 & $\begin{array}{l}\text { Compliance with corporate governance regulations } \\
\text { improves the internal audit recommendations for better } \\
\text { corrective actions. }\end{array}$ & 4.19 & 0.647 & 1 \\
\hline 11 & $\begin{array}{l}\text { Board of directors has an audit committee responsible for } \\
\text { monitoring financial and non-financial compliance } \\
\text { activities of management. }\end{array}$ & 4.15 & 0.780 & 2 \\
\hline 12 & $\begin{array}{l}\text { Internal audit unit and audit committee disclose any } \\
\text { event that may affect the shareholders. }\end{array}$ & 3.89 & 0.840 & 7 \\
\hline 13 & $\begin{array}{l}\text { Internal auditor submits a report to the board of directors } \\
\text { and the audit committee about the company's commitment } \\
\text { to implementing the rules of corporate governance. }\end{array}$ & 3.89 & 0.759 & 7 \\
\hline 14 & $\begin{array}{l}\text { Audit committee provides the necessary recommendations } \\
\text { to activate the governance. }\end{array}$ & 3.83 & 0.892 & 10 \\
\hline 15 & $\begin{array}{l}\text { Internal audit in my firm/audited firms plays an important } \\
\text { role to activate corporate governance. }\end{array}$ & 3.79 & 0.883 & 11 \\
\hline 16 & $\begin{array}{l}\text { Internal audit of my firm/audited firms is effective and } \\
\text { there is reasonable assurance that corporate governance } \\
\text { goals achieved. }\end{array}$ & 3.77 & 0.865 & 13 \\
\hline & Average & 3.87 & 0.905 & \\
\hline
\end{tabular}


CG regulations improves the internal audit recommendations for better corrective actions (statement \#13, mean $=4.19, \mathrm{SD}=0.647$ ). And the statement that refers to management seriously views recommendations and corrective actions from the audit report as an avenue for improvements (statement \#12, mean = $4.06, \mathrm{SD}=0.845)$. The participants' perceptions toward these statements harmonize with Abdullah et al. (2018) as stated that the effectiveness of internal audit impacts CG when internal audit findings could be linked to specific CG areas for improvements to be made by senior management. Over (70\%) of participants agreed to these two statements, reflecting a good quality of the internal audit process in their companies. It can be observed that the results prove that the audit recommendations aid management in making improvements to business processes.

Moreover, over (80\%) agreed with statement \#14 that indicates that the board of directors has an audit committee responsible for monitoring financial and non-financial compliance activities of management (mean $=4.15, \mathrm{SD}=0.780)$. This result confirms that the firms are more likely to report financial fraud without an audit committee (Al-Matari et al., 2012). The results of the statements $(15,16$, and 17) about the audit committee show a mean between (3.83) and (4.14), which represent a strong agreement on the importance of the audit committee role. And that corresponds with Al-Matari et al. (2012), who argued that the audit committee is acting as a governance mechanism.

It is also observed that the vast majority of the respondents are in agreement with statement that the internal audit activates CG. Almost (70\%) of participants agreed to statements \#5 and \#8 (mean $=3.94, \mathrm{SD}=1.092),($ mean $=3.94, \mathrm{SD}=$ 1.009) respectively.

Although about (57.5\%) of the participants agreed to statement \#10, (17\%) of participants disagree with this statement that states that the internal audit unit ensures that shareholders have the right to participate and obtain information about the fundamental changes in the company. As a result, the internal auditors and audit committees should consider the shareholders' right to ensure that the internal audit unit process is aligned with CG objectives.

Overall, the results in Table 7 show a range of the mean between (3.55) and (4.51) and SD between (0.547) and (1.092). This indicates that the research sample believes that effective internal audit has a significant impact on CG and confirmed the effect of the internal audit function in achieving CG objectives. The results of this section support and confirm the second hypothesis:

H2: Effective internal audit enhances corporate governance leading to positive firm performance.

\subsection{The Impact of Successful ERP Systems on CG}

This section presents the results on testing the third hypothesis exploring respondents' perceptions concerning the effect of successful ERP systems on CG and, subsequently, firm performance in Saudi listed companies. The results in Table 8 shows that the highest rank goes to statement \#11 followed by statement 
Table 8. Respondents' perceptions towards ERP systems.

\begin{tabular}{|c|c|c|c|c|}
\hline & Statement & Mean & SD & Rank \\
\hline 1 & $\begin{array}{l}\text { My firm has implemented an ERP system or its } \\
\text { equivalents./Audited firms have implemented ERP } \\
\text { system or its equivalents. }\end{array}$ & 3.87 & 0.824 & 11 \\
\hline 2 & $\begin{array}{l}\text { ERP system has good functions and features which serve } \\
\text { corporate governance and satisfy firms' needs. }\end{array}$ & 3.57 & 0.878 & 18 \\
\hline 3 & $\begin{array}{l}\text { ERP system improves the data accuracy and reduces the } \\
\text { risk of duplicate information. }\end{array}$ & 3.91 & 0.803 & 9 \\
\hline 4 & $\begin{array}{l}\text { ERP system reflects the entire organization and successfully } \\
\text { depict and integrate the data structures of the entire organization. }\end{array}$ & 3.96 & 0.751 & 7 \\
\hline 5 & $\begin{array}{l}\text { Successful ERP implementation reduces the time required } \\
\text { to complete individual tasks and duties. }\end{array}$ & 4.13 & 0.741 & 2 \\
\hline 6 & $\begin{array}{l}\text { Successful ERP implementation improved the access to } \\
\text { information and facilitate information availability. }\end{array}$ & 4.06 & 0.987 & 4 \\
\hline 7 & $\begin{array}{l}\text { Successful ERP implementation enhances information flow } \\
\text { for internal managers and outside stakeholders. }\end{array}$ & 3.77 & 1.026 & 15 \\
\hline 8 & $\begin{array}{l}\text { Successful ERP implementation helped to bridge the } \\
\text { information gaps between all users inside and outside the } \\
\text { firm and reduce the conflicts. }\end{array}$ & 3.79 & 0.858 & 14 \\
\hline 9 & $\begin{array}{l}\text { ERP system in my firm/audited firms plays an important } \\
\text { role to activate corporate governance. }\end{array}$ & 3.74 & 0.820 & 16 \\
\hline 10 & $\begin{array}{l}\text { ERP system in my firm/audited firms helped in controlling } \\
\text { the business and achieving governance objectives. }\end{array}$ & 3.81 & 0.798 & 12 \\
\hline 11 & ERP system reduces the entity's costs. & 4.19 & 0.741 & 1 \\
\hline 12 & $\begin{array}{l}\text { The top management and audit committee are involved } \\
\text { in the implementation of ERP. }\end{array}$ & 3.81 & 0.900 & 12 \\
\hline 13 & $\begin{array}{l}\text { The top management and audit committee involvement are } \\
\text { important in the successful of implementation of ERP project. }\end{array}$ & 4.06 & 0.704 & 4 \\
\hline 14 & $\begin{array}{l}\text { ERP system supports audit committee and top management to } \\
\text { improve firm's performance through corporate governance. }\end{array}$ & 3.98 & 0.642 & 6 \\
\hline 15 & $\begin{array}{l}\text { ERP system emphasizes the significance of corporate } \\
\text { governance practices and adherence to regulations to improve } \\
\text { firm's performance. }\end{array}$ & 3.94 & 0.673 & 8 \\
\hline 16 & $\begin{array}{l}\text { ERP system is efficiently and effectively providing management } \\
\text { with a true picture of the risks the organization faces. }\end{array}$ & 3.74 & 0.736 & 16 \\
\hline 17 & $\begin{array}{l}\text { ERP system ensures that the critical information coming to } \\
\text { the board complementary, accurate and timely in order to } \\
\text { deliver high -quality decision- making. }\end{array}$ & 3.91 & 0.717 & 9 \\
\hline \multirow[t]{2}{*}{18} & $\begin{array}{l}\text { The implementation of ERP system in my firm/audited firms } \\
\text { was successful project. }\end{array}$ & 4.11 & 0.729 & 3 \\
\hline & Average & 3.91 & 0.796 & \\
\hline
\end{tabular}

\#5 that states ERP system reduces the entity's cost and the time required to complete individual tasks and duties (mean $=4.19, \mathrm{SD}=0.741$ ) and (mean $=4.13$, $\mathrm{SD}=0.741)$ respectively. About $(83 \%)$ of participants agree that ERP system im- 
plementation in their firms was a successful project (statement \#18, mean $=4.11$, $\mathrm{SD}=0.729$ ). This indicates that ERP helped in achieve the goals intended from ERP implementation.

The respondents agree that ERP systems are essential and are good information technology tools for the availability of information. The majority of participants agree on statements $(6,7$, and 8$)$ that states the successful ERP implementation improved access to information, enhanced information flow for internal managers and outside stakeholders, and helped to bridge the information gaps between all users inside and outside the firm and reduce the conflicts (mean = between 3.79 and $4.06, \mathrm{SD}=$ between 0.858 and 1.026). This result is consistent with Seddon et al. (2010), who argued that ERP improved access to information and information integration, and with Jidong and Liyan (2010), who argued that ERP implementation enhances information flow for internal managers and external stakeholders, helps resolve principal-agency problems, and improves CG. The results of respondents to the survey matched with these previous studies' findings.

Finney and Corbett (2007) and Al-Turki (2011) have argued that management support is one of the most critical success factors for implementing an ERP system. The study results reveal that $82 \%$ of respondents believe the importance of top management and audit committee involvement to the success of ERP project implementation (statement \#13, mean $=4.06, \mathrm{SD}=0.704$ ). However, only $66 \%$ of the respondents confirmed that top management and audit committee had been involved in the implementation of ERP systems in their organizations (statement \#12, mean $=3.81, \mathrm{SD}=0.900$ ).

Chen et al. (2019) found that information system implementation is associated with better firm performance under some CG aspects. The results of the study show that the vast majority of the respondents agree to statement \#15 which, states that the ERP system emphasizes the significance of CG practices and adherence to regulations to improve firm's performance (statement \#15, mean $=3.94, \mathrm{SD}=0.673$ ).

It is observed that the participants positively agreed to the statement that indicates that the ERP system ensures that vital information is made available to the board constantly and accurately on time to deliver informative decisions (statement \#17, mean $=3.91, \mathrm{SD}=0.717$ ). The result is aligned with Kanellou and Spathis (2013) as they stated that ERP implementation increased flexibility in information generation, improved decision-making based on timely and reliable accounting information.

Overall, the results in Table 8 show the means of all statements above 3.50, which means the great majority of the respondents believed that successful ERP systems are enhancing CG practices. These results lead to the conclusion that ERP has a positive effect on CG which support and confirm the third hypothesis:

H3: Successful ERP systems improve corporate governance practices leading to better firm performance. 


\subsection{Research Reliability}

The reliability of a research is an indicator of a measure's internal consistency; a measure is reliable when the different items in the instrument show a similarly consistent result (Zikmund et al., 2010). Smith (2019) suggested that 0.60 to be an acceptable reliability coefficient level. This research used Cronbach's alpha to measure the reliability of the questionnaire. Reliability tests were carried out on the relationship between CG and firm performance, the impact of effective internal audit on CG, and the impact of successful ERP implementation on CG. Table 9 shows that the Cronbach's alpha of the relationship between CG and firm performance is equal to 0.64 , which is an acceptable value and this finding refers to consistency between items. The alpha of Cronbach of the impact of effective internal audit and successful implementation of ERP on CG are above 0.90 , which is a value close to 1 and this finding refers to consistency between items elements of the construct. The table proves that these results confirm the three hypotheses which have been developed in this research.

\section{Conclusion}

CG has been a hot issue in accounting literature since some major financial manipulation and corporate frauds were observed due to lack of disclosure and poor audit and governing structure. Saudi Arabia has taken the initiative in designing and implementing good CG practices. This study explores the effects of CG on the firm performance of some selected Saudi listed companies listed using internal audit and ERP systems as dependent variables. To accomplish the research objectives, a questionnaire was used. The data were analyzed using SPSS to obtain quantitative measures of descriptive statistics. The findings indicate that there is a positive relationship between corporate governance and firm performance. This study supports the argument that when firms have good CG, performance is expected to improve. This study supports the agency theory perspective that CG may mitigate agency problems, leading to an improvement in the company's performance.

This study concludes that good CG is a vital to companies as it enhances business image, boosts shareholders' confidence, and reduces the risk of fraudulent practices. CG is built on a number of interrelated components, and internal control system is considered to be a key component. All components (board of directors, audit committees, management, internal audit, external audit and internal controls) must function effectively as a whole to bring about good CG.

Table 9. Research reliability.

\begin{tabular}{|c|c|c|}
\hline No & Statement & Cronbach's alpha $(\alpha)$ \\
\hline 1 & The effect of corporate governance on firm performance & 0.64 \\
\hline 2 & The effect of internal audit on corporate governance & 0.93 \\
\hline 3 & $\begin{array}{l}\text { The effect of successfully implemented ERP on corporate } \\
\text { governance }\end{array}$ & 0.92 \\
\hline & Total reliability analysis of questionnaire & 0.95 \\
\hline
\end{tabular}


The results of the study also confirm the importance of the internal audit function in addressing agency problems and the importance of interactions of the audit committees with the internal audit in enhancing CG. The results show the internal audit can be very beneficial to listed companies in the areas of transparency and disclosure of the firms' events. Also, the results prove that the internal auditor recommendations aid management in making improvements to business processes.

Moreover, this study shows that successfully implemented ERP systems improve CG. Information asymmetries lead to principal-agent problems. The core of CG and the existence of ERP systems enhance information flow, mitigate principal-agent problems, and eventually improve CG. The study's findings provide a recommendation for the usefulness of ERP systems and encourage companies to adopt such systems. Companies need to be aware that ERP systems should be successfully implemented to enhance their CG. Listed companies need to strive to adopt ERP systems and plan the implementation process to get the maximum benefits of these systems in improving CG practices.

Based on the study result, special attention should be paid to the training of workforce on CG challenges, issues, and values. Toward this, regular in-service training should be organized for the audit personnel to sharpen their skills to give their best in return. Training must be on a continuous process to keep abreast of the latest developments. Financial market authorities should try to improve and enhance the awareness and skills of internal auditors and audit committee members by holding business conferences or illustrating their roles to enhance their skills and abilities, leading to good CG practices and better performance. For the competencies, there is the tendency for internal audit staff to collectively possess or develop their knowledge or skills through appropriate professional courses and development programs such as obtaining Chattered Accountant or Internal Auditor certification.

Shareholders' rights and voluntary disclosure should be given high priority. The study's findings have implications for firms to increase the internal audit process and reporting quality. Moreover, companies need to provide more effective actions to increase the effectiveness of internal audit functions and internal audit recommendations in making improvements to business processes.

The study has its limitations due to reliance on self-reported answers of participants as it is subject to a common method or the source error (Shaughnessy et al., 2003). Most participants generally answer questions based on what they perceive as a socially desired response. This may bias participants' responses and, consequently, affect the authentic relationship between the variables. Further, a larger sample size could institute better the relationship between the variables in future studies as this would lead to more reliable information. The respondents who contributed to this study did not represent the broad population of Saudi listed companies. This study investigated the perceptions of certain category of stakeholders; hence other shareholders such as investors and regulators might enlighten the research. 
Future research is encouraged to consider other variables that may affect CG and impact firm performance. Future research should conduct similar studies in specific sectors, different contexts (other countries), cross countries studies, and other theories.

\section{Conflicts of Interest}

The authors declare no conflicts of interest regarding the publication of this paper.

\section{References}

Abdullah, R., Ismail, Z., \& Smith, M. (2018). Audit Committees' Involvement and the Effects of Quality in the Internal Audit Function on Corporate Governance. International Journal of Auditing, 22, 385-403. https://doi.org/10.1111/ijau.12124

Abu-Musa, A. A. (2007). Exploring Information Technology Governance (ITG) in Developing Countries: An Empirical Study. The International Journal of Digital Accounting Research, 7, 73-118. https://doi.org/10.4192/1577-8517-v7_4

Ahmad, I., \& Yameen, M. (2015). Impact of Corporate Governance Practices on Financial Performance of Hindustan Petroleum Corporation Limited. International Journal of Advancements in Research and Technology, 4, 135-148.

Ahmed, A. S., \& Duellman, S. (2007). Accounting Conservatism and Board of Director Characteristics: An Empirical Analysis. Journal of Accounting and Economics, 43, 411-437. https://doi.org/10.1016/j.jacceco.2007.01.005

Ahmed, E., \& Hamdan, A. (2015). The Impact of Corporate Governance on Firm Performance: Evidence from Bahrain Bourse. International Management Review, 11, 21-37.

Al-Bassam, W. M., Ntim, C. G., Opong, K. K., \& Downs, Y. (2018). Corporate Boards and Ownership Structure as Antecedents of Corporate Governance Disclosure in Saudi Arabian Publicly Listed Corporations. Business \& Society, 57, 335-377. https://doi.org/10.1177\%2F0007650315610611

Ali, A. M., Ahmi, A., Ali, A., Ghazali, M. Z., Gloeck, J. D., \& Lee, T. H. (2009). Internal Audit in the Federal Organizations of Malaysia: Is There Light at the End of the Long Dark Tunnel? Southern African Journal of Accountability and Auditing Research, 9, 23-38.

Al-Mashari, M. (2003). A Process Change-Oriented Model for ERP Application. International Journal of Human-Computer Interaction, 16, 39-55. https://doi.org/10.1207/S15327590IJHC1601_4

Al-Matari, Y. A., Al-Swidi, A. K., Fadzil, F. H. B. H., \& Al-Matari, E. M. (2012). Board of Directors, Audit Committee Characteristics and the Performance of Saudi Arabia Listed Companies. International Review of Management and Marketing, 2, 241-251.

Al-Shetwi, M., Ramadili, S. M., Chowdury, T. H. S., \& Sori, Z. M. (2011). Impact of Internal Audit Function (IAF) on Financial Reporting Quality (FRQ): Evidence from Saudi Arabia. African Journal of Business Management, 5, 11189-11198.

Al-Turki, U. M. (2011). An Exploratory Study of ERP Implementation in Saudi Arabia. Production Planning \& Control, 22, 403-413. https://doi.org/10.1080/09537287.2010.491490

Anwar, Z., \& Aziz, B. (2019). Does Corporate Governance Stimulate Firm Performance? Assessing Corporate Governance Practices toward Social Welfare. New Horizons, 13, 107-126. 
ASX Corporate Governance Council (2006). Review of the Principles of Good Corporate Governance and Best Practice Recommendation, Australian Stock Exchange, Sydney.

Bananuka, J., Nkundabanyanga, S. K., Nalukenge, I., \& Kaawaase, T. (2018). Internal Audit Function, Audit Committee Effectiveness and Accountability in the Ugandan Statutory corporations. Journal of Financial Reporting and Accounting, 16, 138-157. https://doi.org/10.1108/JFRA-07-2016-0062

Buallay, A., Hamdan, A., \& Zureigat, Q. (2017). Corporate Governance and Firm Performance: Evidence from Saudi Arabia. Australasian Accounting, Business and Finance Journal, 11, 78-98. http://dx.doi.org/10.14453/aabfj.v11i1.6

Chen, X., Dai, Q., \& Na, C. (2019). The Value of Enterprise Information Systems Under Different Corporate Governance Aspects. Information Technology and Management, 20, 223-247. https://doi.org/10.1007/s10799-019-00310-3

CMA (Capital Market Authority) (2006). Corporate Governance Regulations in Kingdom of Saudi Arabia. Riyadh: Capital Market Authority.

Committee of Sponsoring Organizations of the Treadway Commission, COSO (1992). Internal Control-Integrated Framework: Evaluation Tool. New York.

Committee of Sponsoring Organizations of the Treadway Commission, COSO (2013). Internal Control-Integrated Framework.

Dănescu, T., Prozan, M., \& Dănescu, A. C. (2011). Internal Control Activities: Cause and Effect of a Good Governance of Accounting Reportings and Fiscal Declarations. Annales Universitatis Apulensis Series Oeconomica, 2, 339-349.

Ebelechukwu, E., Yakubu, Sh., \& Paul, G. (2015). Impact of Corporate Governance on Financial Performance of Microfinance Banks in North Central Nigeria. Strategic Management Journal, 19, 269-290.

Fadilah, S. (2013). The Influence of Good Governance Implementation to Organization Performance: Analysis of Factors Affecting. The International Journal of Social Sciences, 7, 15-33.

Fallatah, Y., \& Dickins, D. (2012). Corporate Governance and Firm Performance and Value in Saudi Arabia. African Journal of Business Management, 6, 10025-10034.

Finney, S., \& Corbett, M. (2007). ERP Implementation: A Compilation and Analysis of critical Success Factors. Business Process Management Journal, 13, 329-347.

Gillan, S. L. (2006). Recent Developments in Corporate Governance: An Overview. Journal of Corporate Finance, 12, 381-402. https://doi.org/10.1016/j.jcorpfin.2005.11.002

Gillan, S. L., \& Starks, L. T. (1998). A Survey of Shareholder Activism: Motivation and Empirical Evidence. Contemporary Finance Digest, 2, 10-34.

Giroux, G., \& Cassell, C. (2011). Changing Audit Risk Characteristics in the Public Client Market. Research in Accounting Regulation, 23, 177-183.

Holbrook, A. L., Krosnick, J. A., \& Pfent, A. (2007). Causes and Consequences of Response Rates in Surveys by the News Media and Government Contractor Survey Research Firms. In J. M. Lepkowski et al. (Eds.), Advances in Telephone Survey Methodology (pp. 499-528). New York: Wiley.

Jensen, M. C., \& Meckling, W. (1976). Theory of the Firm: Managerial Behavior, Agency Costs and Ownership Structure. Journal of Financial Economics, 3, 305-360. https://doi.org/10.1016/0304-405X(76)90026-X

Jidong, Z., \& Liyan, W. (2010). ERP Implementation: A Corporate Governance Perspective. International Journal of Public Information Systems, 6, 33-42.

Joksimović, M., \& Alseddig, A. (2017). The Internal Audit as Function to the Corporate 
Governance. Megatrend Revija, 14, 109-125. https://doi.org/10.5937/MegRev1702109J

Kanellou, A., \& Spathis, C. (2013). Accounting Benefits and Satisfaction in an ERP Environment. International Journal of Accounting Information Systems, 14, 209-234. https://doi.org/10.1016/j.accinf.2012.12.002

Lopes, P. F. (1992). CIM-II: The Integrated Manufacturing Enterprise. Industrial engineering, 24, 43-45.

Martin, K., Sanders, E., \&, Scalan, G. (2014). The potential Impact of COSO Internal Control Integrated Framework Revision on Internal Audit Structured SOX Work Programs. Research in Accounting Regulation, 26, 110-117.

Olumbe, C. (2012). The Relationship between Internal Control and Corporate Governance in Commercial Banks in Kenya. Master's Thesis, University of Nairobi, Nairobi.

Parkinson, J. (1994). The Legal Context of Corporate Social Responsibility. Business Ethics: A European Review, 3, 16-22. https://doi.org/10.1111/j.1467-8608.1994.tb00056.x

Sarens, G. (2009). Internal Auditing Research: Where Are We Going? Editorial. International Journal of Auditing, 13, 1-7. https://doi.org/10.1111/j.1099-1123.2008.00387.x

Seddon, P., Calvert, C., \& Yang, S. (2010). A Multi-Project Model of Key Factors Affecting Organizational Benefits from Enterprise Systems. MIS Quarterly, 34, 305-328.

Shaiti, H. (2014). The Relationship between ERP Systems Success and Internal Control Procedures: A Saudi Arabian Study. Doctoral Dissertation, Luton: University of Bedfordshire.

Shaughnessy, J. J., Zechmeister, E. B., \& Zechmeister, J. S. (2003). Research Methods in Psychology (6th ed.). New York, NY: McGraw Hill.

Škare, M., \& Hasić, T. (2016). Corporate Governance, Firm Performance, and Economic Growth-Theoretical Analysis. Journal of Business Economics and Management, 17, 35-51. https://doi.org/10.3846/16111699.2015.1071278

Smith, M. (2019). Research Methods in Accounting ( $5^{\text {th }}$ Edition). London: SAGE Publications Limited.

Solomon, J. (2007). Corporate Governance and Accountability (2nd ed.). Hoboken, NJ: John Wiley \& Sons.

Verboncu, I., \& Zalman, M. (2005). Management şi performante. Editura Universitară.

Vijayakumar, A. N., \& Nagaraja, N. (2012). Internal Control Systems: Effectiveness of Internal Audit in Risk Management at Public Sector Enterprises. BVIMR Management Edge, 5, 1-8.

Vlad, M. (2012). The Corporative Governance and Internal Audit. Case Study: Romanian Credit Institutions. The USV Annals of Economics and Public Administration, 12, 164-169.

Zhang, L., \& Huang, J. H. (2012). The Moderating Factors in the Relationship between ERP Investments and Firm Performance. Journal of Computer Information Systems, 53, 75-84.

Zikmund, W. G., Babin, B. J., Carr, J. C., \& Griffin, M. (2010). Business Research Methods (8th ed.). Canada: South Western Cengage Learning. 